many days of perfect calm; the summer was, however, more stormy than the winter. The winds came chiefly from the west-those from a dic westerly direction being most common -and also from wcst-south-wcst or north-west. The westerly and south-westerly winls were during the winter the warmest, which is ascribed to the circumstance that they passed over mountains some 6000 feet in height, which rendered them "Föhn-like." The barometer readings were never attended by violent storms; these occurred without exception when the glass stood at "fair." 'There was no aurora australis, nor were there any thunderstorms.

Explorations of the island were undertaken on several occasions, and many of the peaks in the neighbourhood of Royal Hay were climbed. The slate rocks were very difficult of ascent. The enormous glacicrs in the mountains of the interior prevented, unfortunately, any thorough exploration of this part. The mountains often sloped alruply int, the sea, and the highest points were about ten milcs from the station and covered with eternal snow. The roar of avalanches was continually heard. The fauna was very poor. That such a clreary climate should boast of a very extensive fauna or flora was hardly to be expected ; nevertheless, the mosses were very fine. Dr. H. Will, the botanist, collected about thirty varieties. They show what a climate where the sun is nearly always absent can produce in the way of plants which arc able to resist rapid changes of temperaturc, but the fauna is one which may at once be said to belong to more Antarctic regions than Terra del Fuego, the Kerguelen Islands, and more northerly places. It is a repetition of the same types, with originality in,details alonc.

\section{CARTOGRAPHICAL WORK IN RUSSIA}

WE learn from a recent issue of the I3vestir of the Russian Geographical Society that the following geodetical and cartographical work was done during the year I 883 by the officers of the Russian General Staff. The first-class triangulation for connecting the line of Warsaw and Grodno with that of the Vistula was continued; the secondary network of triangulation was extended in Lithuania and Poland; and the heights of 262 places were determined by careful levellings. The most useful work of exact levellings on the Russian railways, undertaken several years since, was continuted in West and South-West Russia, leading to a precise measurement of the differences of level between the Baltic and the Black Seas, and the final results are now being calculated. The Russian survey was continued on the scales of 1400 and 1750 feet to an inch, in Poland, Lithuania, Bessarabia, and Finland ; and a most welcome feature of it is that great attention was given to the measurements of heights, so that a map with level-lines only, 35 to 70 feet apart from one another, may be published. In the Caucasus very accurate measurements of the latitudes and longitudes of Tiflis, Baku, and Shemakla were made, as also pendulum observations in Trans-Caucasia. Of trigonometrical mcasurements, the triangulation of the Trans-Caspian region was continued as far as the Persian frontier, and that of Akhal-Tekke, was also calculated. An interesting feature of this last was the measurcment of two geodetical bases on strings which methnd gives, as is known, very satisfactory results - together with a inuch greater economy of time. Detailcd surveys were continued in several parts of the Caucasus, those at Askabad, and between Kyzil-Arvat, Bami, and the Sumbar River (two versts to an inch) being especially worthy of notice.

In Turkestan, at the 'Tashkend Observatory, Col. Pomcrantseff continued his observations of minor planets with the refractor of the Observatory, and the mcasurement of stars by means of the meridian-circle; and his assistant, Capt. Zalcssky, regularly made measurements of occultations of stars by the moon. The work of the Observatory will soon he publisher, and will contain an elaboralc paper by Dr. Schwartz, on magnetism in Turkestan. Several most valuable determinations of latimies and longitude werc made by M. Putyata in the Pamir during M. Ivanoff's expedition. Among many surveys which were made this year, that of the northern slope of the Turkestan ridge was especially interesting, no less than twenty-three unknown glaciers having been discovered at the sources of the Sokh, and mapped. The Shemanovsky glacier, eight miles long, and that of Ak-terek, twenty-two miles long, which joins the well-known Zarafshan glacier, are especially worthy of notice. A survey of the rich oasis of Karshi, and of the Bokhara dominions on the right bank of the Zarafshan, is also very interesting. The map of Turkestan on the scalc of ten versts (seven miles) to an inch, is already in print, and several sheets are nearly ready.

In the Omsk military district we notice several determinations of latitudes and longitudes, as also the survey of the Kirghiz Steppe, on a scaite of five versts to an inch. In Eastern Siberia the chief work was the further extension of the triangulation of Trans-Baikalia-a most necessary work, on accoint of the scarcity of determined points to fix the surveys in that regionand many local surveys, those in the Ussuri region and on the Pacific coast bcing. especially interesting. The astronomically determined points, very few on the whole, have received only seven additions.

The Hydrographical Department has pursued its work on the Baltic, the Black, and the Caspian Seas, as also on some lakes in the interior of Russia and Finland ; the most interesting of them being several detailcd maps of the Lake of Onega, and the Lakes Päyänne and Pielis, in Finland ; the triangulation and surveys on the Caucasian coast of the Black Sea; and the survey of the Gulf Mortvyi Kultuk of the Caspian.

Among the publications of the General Staff we notice the thirty-ninth volume of its Mencirs, which contains the following papers :-On the triangulation of liessarabia, by Col. Lebedeff; on the difference between the longitudes of Tashkend and Vernyi, by $\mathrm{Col}$. Pomerantseff; on astronomical determinations made in Trans-Baikalia (fifty-two placcs), by Capt. Polanovsky ; in the Altay region and in West Siberia (thirtcen places), by Col. Miroshnitchenko; in the Trans-Caspian region (with a map), by Col. Gladysheff; and in North-West Mongolia, by Lieut. Rafailoff; on levellings on Russian railways ; on the determination of time by means of the meridian-circle, by M. Gladysheff; on the Trans-Caspian triangulation (ninety-two places), by Capt. Pervas, in which it is stated that Askabad is 827 feet, and Mount Riza, on the Persian frontier, 974I feet, above the sealevel ; and finally, a description by Col. Alexandroff of the route from Kungrad to the Gulf of Mortvyi Kultuk, the distance heing 300 miles, of which about 90 miles are without water.

The Annual Report of the Hydrographical Department contains seven small maps showing the exact results of the surveys made on the Russian coasts up to 1882 ; and a paper by $M$. Goloviznin gives at the same timc a sketch of the hydrographical work done by the Rusvian flect since its first formation in 1696 .

\section{SCIENTIFIC SERIALS}

In the Fournal of Botany for January Mr, H. N, Ridley describes and figures the extremely rare foncus tenuis, a plant entirely lust to Britain since 1795 or 1796 , when it was gathered by G. Don in Clova, till $188_{3}$, when it was rediscovered by $\mathrm{Mr}$. Towndrow in Herefordshire. Mr. W. H. Beeby records another interesting addition to the British flora in a new Sparganium, which he names $S$. neglectum, nearly allied to $S$. ramosum, and probably a sub-species of it, found in ponds in several parts of surrey.

THE last part of the Belgiquz? Horticole that has reached us, that for May and June 1884 , contains but little that is original, the substantial articles being taken from French, German, or English journals. The coloured plates of new or little-known plants, with accompanying descriptions, are of their usual excellence, and there are many short paragraphs of interest to horticulturists.

\section{SOCIETIES A.VD ACADEMIES LONDON}

Royal Society, January $29 .-$ "On some Physical Properties of Ice and on the Motion of Glaciers, with special reference to the late Canon Moseley's Objections to Gravitation Theorics." By Coutts Trotter, M.A., Fellow of Trinity Collegc, Cambridge. Communicated by Prof. Stokes, Ser. R.S.

Canon Moseley's theory of glacier motion, pul forward in 1855, has never been accepted by persons conversant with glaciers. In 1869, however, he pht forward a somewhat formidable objection to the current gravitation theories of glacier motion.

The gist of the objection is that the resistance of icc to shearing is many times greater than the shearing force which can be produced in a descending glacier by gravity; and that thcrefore the shearing which the measurements of Forbes and 